\title{
Distribution Pattern and Seasonal Variation of Bird Species from Semi-Urban Area of Taungoo Environs
}

\author{
San San 0o ${ }^{*}$, Nyo Nyo Aung1, Aye Aye Khine1, Myo Sandar Win1, San Aung1, Tun Tun Myint1, \\ Khin Khin Yone1, Nwe Nwe Aung2, Khin Maw Maw Myint², Aung Aung33, Khin Mar Lwin', \\ Soe Soe Win ${ }^{5}$, Nyunt Nyunt 0o6, Biak Khun Aye ${ }^{7}$
}

${ }^{1}$ Zoology Department, University of Yangon, Yangon, Myanmar

${ }^{2}$ Zoology Department, East Yangon University, Yangon, Myanmar

${ }^{3}$ Zoology Department, Taungoo Uniersity, Taungoo, Myanmar

${ }^{4}$ Zoology Department, Kyaing Tong Uniersity, Kyaing Tong, Myanmar

${ }^{5}$ Zoology Department, Dagon University, Yangon, Myanmar

${ }^{6}$ Department of Zoology, Hpaan University, Hpann, Myanmar

${ }^{7}$ Zoology Department, Hakar Uniersity, Hakar, Myanmar

Email: *sansanooyu@gmail.com

How to cite this paper: Oo, S.S., Aung, N.N., Khine, A.A., Win, M.S., Aung, S., Myint, T.T., Yone, K.K., Aung, N.N., Myint, K.M.M., Aung, A., Lwin, K.M., Win, S.S., Oo, N.N. and Aye, B.K. (2020) Distribution Pattern and Seasonal Variation of Bird Species from Semi-Urban Area of Taungoo Environs. American Journal of Operations Research, 10, 111-121.

https://doi.org/10.4236/ajor.2020.104007

Received: May 15, 2020

Accepted: June 29, 2020

Published: July 2, 2020

Copyright ( 2020 by author(s) and Scientific Research Publishing Inc. This work is licensed under the Creative Commons Attribution International License (CC BY 4.0).

http://creativecommons.org/licenses/by/4.0/

\section{(c) (i) Open Access}

\begin{abstract}
The environs of Taungoo Township, Bago Region are one of the high biodiversity areas in Myanmar, locating eastern side of the high mountain ranges of Middle Yoma. The dense of every green and deciduous forest in the middle Middle Yoma were logging since 10 - 20 years ago. The birds inhabiting in that area have to refuge in suitable habitats nearby. The resent status of bird species is needed to assess the diversity of birds with the respect to distribution and seasonal variation after the construction of Yangon-Nepyitaw, Myanmar after twenty years ago. A total of 50 species of 27 genera, 22 families under nine orders were recorded. That represented 44 resident species (32 terrestrial species and 12 water bird species), and 6 species of migratory birds (1 terrestrial species and 5 water bird species). As habitat utilization, 24 bird species in paddy fields, 21 species in scattered trees, 33 species in wetland and 25 species in forest habitat types were investigated. Some species used more than one habitat types. According to the assessment of abundance categories based on the calculation of individual numbers of the birds, abundant category ( 3 species), common bird (1 species), frequent category ( 5 species), uncommon category (3 species) and rare species ( 28 species) were categorized. Hence, bird community was still sustainable in this area. In the aspect of conservation status, all recorded bird species were under least concern categories, according to the IUCN Redlist in the study area.
\end{abstract}




\section{Keywords}

Species Diversity, Birds, Habitat Utilization, Taungoo Environs

\section{Introduction}

The Middle Yoma Mautain Range is running along the middle of Myanmar country from north to south tip. The evergreen forests and misdeciduous forest, including valuable trees of teaks and many other trees grow dense in this range. The forests were depleted during the time of Yangon-Nepyitaw highway road construction. The range is the east side of Taungoo Township, the study site area. In the Middle Mountain range of Myanmar, the forest ecosystem is fantastic with very high species diversity. The canopy cover is very thick and we cannot see the sun even at the noon time in the forest. After depletion of those forests, the dependent forest fauna species face with habitat loss, habitat fragmentation consequencely. The question is that where the forest dependent species including birds move to.

The birds are highest diverse animal group after fishes and approximately 10,000 species of birds have described in the world. In Myanmar, the bird species is 1026 species including 9 endemic species. They eat different food types, grains, sees, fruits, nactare, etc. and use different habitat types. It is also an important indicator of environmental condition. Species diversity representing species richness and individual numbers of particular species of the birds can also assess the condition of the habitats of any ecosystem. Myanmar is one of the highest biodiversity areas (Gill, 1994) [1].

Naw Lawlar Phaw (2016) [2] conducted the research on the status of bird fauna from vicinity of Taungoo Township, Bago Region. She categorized the habitat types into five study sites. She recorded a total of 40 species belong to 27 genera under 22 families of nine orders. It was categorized as 29 species of resident birds and 11 species of migratory birds representing 27 species of terrestrial bird and 16 species of water birds. Moe Moe Dwe (2014) also investigated and recorded the 26 bird species from the same study site, Taungoo Township [3].

The distribution pattern of the birds depends on the habitat types of foraging and roosting grounds. Some birds used the same habitat type for feeding and roosting while the others are not. The food availability of food types and amount also depends on the seasonal variation. More the availability of the food types and food amount, the more bird species and numbers is. During the age of species diversity loss, we can compare and check what species are disappear or locally species loss. Although no previous data of this area, it is essential to assess and record of the bird diversity of Taungoo environs.

\section{Materials and Methods}

\section{Study area, study sites and study period}


The present study conducted the distribution patterns of bird species at site in Taungoo environs. Site I is located between $18^{\circ} 52^{\prime} 0^{\prime \prime} \mathrm{N}$ to $18^{\circ} 60^{\prime} 0^{\prime \prime} \mathrm{N}$ and $96^{\circ} 15^{\prime} 0$ "E to $96^{\circ} 27^{\prime} 0^{\prime \prime E}$. Site II was conducted in Taungoo environs located between $18^{\circ} 58^{\prime} 40^{\prime \prime} \mathrm{N}$ and $96^{\circ} 31^{\prime} 0$ "E. (See Figure 1) These two sites were categorized into four habitats as follows: Study site I, Paddy field: Area around Nat Sin Gon village (18 $59^{\circ} 31.40^{\prime \prime N}$ and $\left.96^{\circ} 17^{\prime} 40.15^{\prime \prime E}\right)$; Study site II, Scattered Trees: Along the road sides of Saba Oo village (18 $56^{\prime} 23.04^{\prime \prime} \mathrm{N}$ and $\left.96^{\circ} 17^{\prime} 53.80^{\prime \prime} \mathrm{E}\right)$; Study site III, Wetland: PyinKye Inn, Gyo Bin Zeik village ( $18^{\circ} 58^{\prime} 53.49^{\prime \prime} \mathrm{N}$ and $\left.96^{\circ} 15^{\prime} 54.77^{\prime \prime} \mathrm{E}\right)$; Study site IV, Forest type: Saba Gywe village ( $18^{\circ} 57^{\prime} 17.87^{\prime \prime} \mathrm{N}$ and $\left.96^{\circ} 18^{\prime} 29.21^{\prime \prime E}\right)$. The study period lasted from June, 2016 to May, 2017.

\section{Bird watching and identification used in field}

Bird survey in the study area was followed after Bibby, et al., (1998) [4]. A binoculars and digital camera power shot $(5 \times 50 \mathrm{Hs})$ were used for observing the plumage colours and patterns of the birds and for taking bird photographs to confirm the species for further investigation. Identification of bird species in the field survey was followed after Robson (2008) [5], Kyaw Nyunt Lwin and Khin Ma Ma Thwin (2003) [6] and Smythies (1986) [7].

\section{Data collection}

Bird watching was weekly conducted in the morning from 6:00am-11:00am and in the afternoon from 3:00pm-6:00pm. Number of birds, and bird activity and habits (flying, feeding, perching, restinf and singling or corple or groups) were noted down in field data form. Point count method was used in this study.

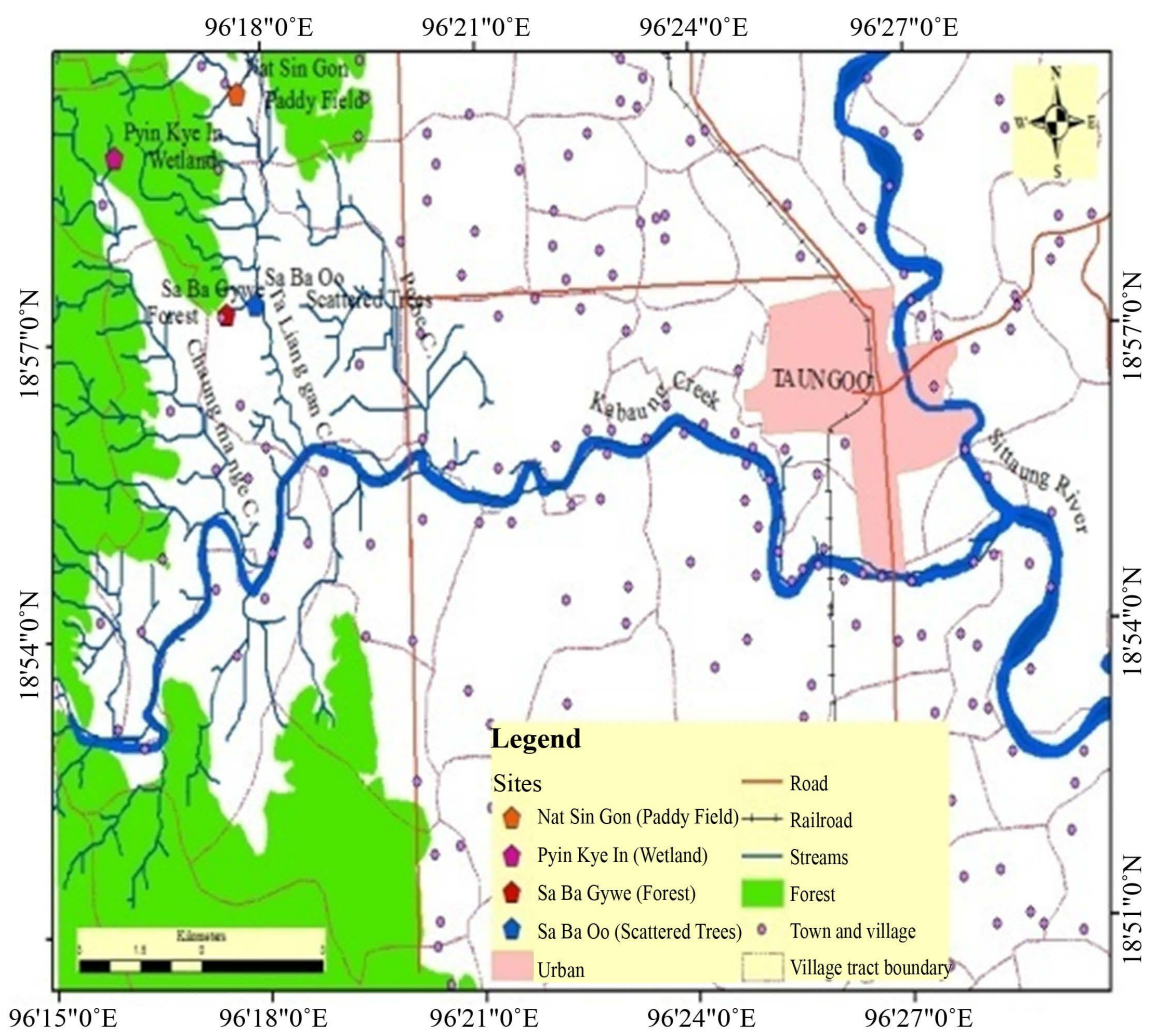

Figure 1. Map of Taungoo environs showing the two study sites. Source: UDN. 


\section{Data analysis}

The abundance category indicating individual numbers of birds of each species was followed after Kumar and Sivaperuman (2005) [8] and was calculated as the formula mentioned below:

$$
\text { Relative abundance }=\frac{\text { Total numbers of particular species }}{\text { Total species }} \times 100
$$

Abundance categories were determined based on index values as follows:

$$
\begin{aligned}
& \text { Rare Species }=(0.1-2.0) \quad \text { Common }=(6.1-8.0) \\
& \text { Uncommon }=(2.1-4.0)
\end{aligned} \begin{aligned}
& \text { Abundant }=(8.1-\text { above }) \\
& \text { Frequent }=(4.1-6.0) \\
& \quad \text { Dominance index }=\frac{\text { No. of individual of each species }}{\text { Total number of individuals of all species }} \times 100
\end{aligned}
$$

Shannon index and Evenness formula were used for the assessment of bird species diversity as follow (Stilling, 1999) [9]. Shannon indix vlue can assess the rare species of birds.

$$
\begin{gathered}
\text { Shannon Index }=H^{\prime}=\sum P i \ln P i \\
\text { Shannon Index }=H^{\prime} / S \\
P i=\frac{\text { No. of individual of each species }}{\text { Total number of individuals of all species }} \times 100
\end{gathered}
$$

where, $(\operatorname{Ln})=\log$ Normal, $S=$ Total numbers of species.

\section{Results and Discussion}

A total of 50 bird species belonging to 28 families under 10 orders were observed during the study period. Among the 50 bird species, 17 species of waterbirds belong to five migratory species and 33 species of terrestrial bird belong to one species of migratory bird were recorded in the study sites (Table 1). The species, Arcridotheres tristis was recorded as the largest number (217 birds) and the second largest number was that of Hirundo rustica (203 birds) and third one was Passer domesticus (175 birds). These species could be assumed as the most common bird species. The least numbers was from the species Ariceda jerdoni (5 birds) and the second least ones two species, Muscicappa datuurica and Ardeola grayii ( 8 birds in each species). These species were the rare species according to the observed numbers of birds. Eight species recorded under observed numbers of 20 individual also could be assumed as the rare species. These species might be under selection pressure and need to investigate the kinds and degreeof impacts on those species urgently (Table 6). NawLaw Lar Phaw (2016) recorded 17 water bird species, 33 terrestrial bird species, 37 resident bird species and 13 migratory bird species in the Taungooenvirons. The species composition of recorded avifauna was found to vary from one place to another due the different condition of ecosystem, however, the present study area was very near to that her study site. Hence the recorded bird species composition still constant due to environmental condition was still unchanged [2]. 
Table 1. Status of the bird species recorded from Taungoo environs.

\begin{tabular}{cccc}
\hline Bird status & Terrestrial birds & Water birds & Total No. of species \\
\hline Resident birds & 32 & 12 & 44 \\
Migratory birds & 1 & 5 & 6 \\
Total No. of species & 33 & 17 & 50 \\
\hline
\end{tabular}

Naw Tarmalar Htoo (2007) recorded 93 species of birds in relation to 45 species of water birds and 49 species of terrestrial birds in her study period at Moyingyi Wetland Wildlife Sanctuary. She studied the community structure of Avifauna based on seasonally and was longer than that of present work [10].

Species richness of birds recorded from this study could be assumed as relatively high. Total of 46 bird species recorded from Thanlyin environs [11]. The present survey time duration was longer than that of present work. According to the current status of recorded bird species, 17 species of water birds including five migatrory species and 33 species of terrestrial birds including one migratory species were examined. Observed numbers of birds were 893 water birds, 1773 birds of terrestrial birds, 2071 individuals were resident birds and 596 individuals were migratory birds. Observed numbers of birds were the highest in the resident bird species and the second highest numbers was terrestrial bird species. It could be assumed that this finding was highly acceptable because the survey site was only in the land area (Table 1 and Table 2).

Most resident bird species were terrestrial birds ( 28 species of terrestrial birds out of 37 resident species), only 9 species were resident water birds. Most migratory species were water birds ( 8 species of water birds were out of 13 migratory birds and three resident migratory bird species (Table 1 ).

According to the recorded numbers of birds, highest numbers were found in wetland habitat (1212 individuals of birds), the second highest numbers were from paddy field (548 birds) and the third one was from the forest (450 birds) and the lowest one from scattered trees (440 birds) (Table 2).

In the present study, four habitat types were categorized. According to the habitat preference, 24 species of birds were observed from paddy field, 21 species were from scattered habitat, 33 species were examined from wetland habitat and 25 species were from forest habitats (Table 3 and Table 4 ).

The distribution of animal behavior including is positively correlated with availability of potential food sources. In the cool season, the flowering plants blooms and fruiting and ripening times of the plants. Consequently, the numerous insects of different species are also found. Then, the migratory birds are also visiting to southern part of the Asian mainland. The birds have predominately in the cool season in numbers and species (Table 3). All birds including the males and females are assemblage to the breeding sites for display, paring and mating performance. This is also the flowering times abundance season of potential food sources as e flying insects and according to the nature of birds, this is the time of display. The observability is also higher in cool season than other two seasons, because, the canopy cover is clear to observe the bird species. 
Table 2. Numbers of birds and bird seciesrecorded from different habitat types.

\begin{tabular}{cccccc}
\hline Current status & Paddy field & Scattered trees & Wetland & Forest & Total \\
\hline Numbers of species & 24 & 21 & 33 & 25 & 50 \\
Numbers of birds & 548 & 440 & 1212 & 467 & 2667 \\
\hline
\end{tabular}

Table 3. Seasonal variation of birds and bird species in the study area.

\begin{tabular}{ccccc}
\hline Birds and seasons & Dry season & Wet season & Cool season & Total \\
\hline Numbers of species & 33 & 24 & 45 & 50 \\
Numbers of birds & 838 & 715 & 1109 & 2667 \\
\hline
\end{tabular}

Table 4. Abundance category of bird species in the present study area.

\begin{tabular}{cccccc}
\hline Abundance categories & Abundance & Common & Frequent & Uncommon & Rare \\
\hline Numbers of species & 2 & 2 & 3 & 7 & 36 \\
\hline
\end{tabular}

The abundance categories of bird species in the community is importance indication for the sustainability and healthy of ecosystem. The ecosystem will be imbalance and rare and small group species might be excluded if the abundance species are many and occupy almost all trophic levels. In the environs of Taungoo district, rare species are of majority and other trophic levels, common, the bird species of the frequent, uncommon were least number ( 2 species, 2 species, 3 species and 7 species) respectively (Table 4). Hence, this study area of Taungoo environs has the balance ecosystem.

Most of the bird species were resident birds (44 species), representing 32 terrestrial species and 12 water birds. Only 6 migratory bird species were recorded with referring to one terrestrial and five water bird species (Table 5). That indicated the habitat type was predominated with trees or forest bird specis. Very few migratory bird species, Bulbulccs ibis (105 individuals), Ardeola grayii (8 individuals), Actitis hypoleucos (82 individuals), Ardea bacchus (44 ndividuals), and Pandion haliaetus (127 individuals) were found in this area. The first four species were water migratory birds and the last species was terrestrial migratory bird (Table 6).

Four habitat types, paddy field, scattered trees, wetland and forest habitat, were categorized to assess the habitate preference of the bird species. In the present study, the most numbers of species and the numbers of birds were observed from the wetland survey site and it could be assumed as the best habitat type. The area of this wetland is approximately three hactares, into which two streams are running across the study area. This wetland is continuous with paddy fields and cover around it. This wetland serves as water retained area, water from the paddy fields is going into it during the rainy season, and water from the wetland supply in to the paddy fields during the dry season (Table 5).

The trees in the forest area are not highly dense; the local peoples usually cut the woods from it for the fuals in domestic uses. Anyway, the forest trees support 
Table 5. Recorded bird species of different habits from the Taungoo environs.

\begin{tabular}{cccc}
\hline & No. of Resident bird species & No. of Migratory bird species & Total \\
\hline Terrestrial bird species & 32 & 1 & 33 \\
Water bird species & 12 & 5 & 17 \\
Total species & 44 & 6 & 50 \\
\hline
\end{tabular}

Table 6. Habitat preference of bird species and status of bird species.

\begin{tabular}{|c|c|c|c|c|c|c|c|c|}
\hline No. & Scientific name & $\begin{array}{l}\text { Paddy } \\
\text { field }\end{array}$ & $\begin{array}{c}\text { Scattered } \\
\text { tree }\end{array}$ & Wet-land & $\begin{array}{c}\text { Forest } \\
\text { habitat }\end{array}$ & $\begin{array}{c}\text { Bird } \\
\text { status }\end{array}$ & Total & IUCN \\
\hline 1 & Dicrurus macrocercus & 25 & 30 & 60 & 56 & $\mathrm{~T}, \mathrm{R}$ & 171 & $\mathrm{LC}$ \\
\hline 2 & Dicrurus leucophaeus & - & 12 & 15 & 20 & $\mathrm{~T}, \mathrm{R}$ & 47 & $\mathrm{LC}$ \\
\hline 3 & Dicrurus aeneus & - & 5 & - & 7 & $\mathrm{~T}, \mathrm{R}$ & 12 & $\mathrm{LC}$ \\
\hline 4 & Corvus splendens & 40 & 12 & 23 & - & $\mathrm{T}, \mathrm{R}$ & 75 & $\mathrm{LC}$ \\
\hline 5 & Dendrocitta vagabunda & - & - & 13 & 5 & $\mathrm{~T}, \mathrm{R}$ & 18 & $\mathrm{LC}$ \\
\hline 6 & Motacilla alba & - & 20 & 50 & - & $\mathrm{T}, \mathrm{R}$ & 70 & $\mathrm{LC}$ \\
\hline 7 & Passer domesticus & - & 75 & 100 & - & $\mathrm{T}, \mathrm{R}$ & 175 & $\mathrm{LC}$ \\
\hline 8 & Passer flaveolus & - & 6 & - & 10 & $\mathrm{~T}, \mathrm{R}$ & 16 & $\mathrm{LC}$ \\
\hline 9 & Pycnonotus atriceps & - & 3 & 8 & 2 & $\mathrm{~T}, \mathrm{R}$ & 13 & $\mathrm{LC}$ \\
\hline 10 & Pycnonotus blanfordi & - & 8 & 8 & 2 & $\mathrm{~T}, \mathrm{R}$ & 18 & $\mathrm{LC}$ \\
\hline 11 & Pycnonotus cafer & 15 & 24 & 10 & 1 & $\mathrm{~T}, \mathrm{R}$ & 50 & $\mathrm{LC}$ \\
\hline 12 & Sturnus burmannicus & 25 & 30 & 35 & 30 & $\mathrm{~T}, \mathrm{R}$ & 120 & $\mathrm{LC}$ \\
\hline 13 & Arcridotheres fuscus & - & 6 & - & 14 & $\mathrm{~T}, \mathrm{R}$ & 20 & $\mathrm{LC}$ \\
\hline 14 & Arcridotheres tristis & 45 & 30 & 70 & 72 & $\mathrm{~T}, \mathrm{R}$ & 217 & $\mathrm{LC}$ \\
\hline 15 & Lanius cristatus & 30 & - & 28 & - & $\mathrm{T}, \mathrm{R}$ & 58 & $\mathrm{LC}$ \\
\hline 16 & Lanius schach & 5 & - & 6 & - & $\mathrm{T}, \mathrm{R}$ & 11 & $\mathrm{LC}$ \\
\hline 17 & Centropus sinensis & 7 & 3 & - & 2 & $\mathrm{~T}, \mathrm{R}$ & 12 & $\mathrm{LC}$ \\
\hline 18 & Eurystomus orientalis & - & - & - & 35 & $\mathrm{~T}, \mathrm{R}$ & 35 & LC \\
\hline 19 & Nectarinia asiatica & 18 & 22 & - & 53 & $\mathrm{~T}, \mathrm{R}$ & 93 & $\mathrm{LC}$ \\
\hline 20 & Muscicapa dauurica & - & - & - & 8 & $\mathrm{~T}, \mathrm{R}$ & 8 & $\mathrm{LC}$ \\
\hline 21 & Hirundo rustica & 50 & 60 & 40 & 53 & $\mathrm{~T}, \mathrm{R}$ & 203 & $\mathrm{LC}$ \\
\hline 22 & Saxicola caprata & 5 & - & 8 & - & $\mathrm{T}, \mathrm{R}$ & 13 & $\mathrm{LC}$ \\
\hline 23 & Oriolus tenuirostris & - & - & - & 12 & $\mathrm{~T}, \mathrm{R}$ & 12 & $\mathrm{LC}$ \\
\hline 24 & Alauda gulgula & 17 & - & - & - & $\mathrm{T}, \mathrm{R}$ & 17 & $\mathrm{LC}$ \\
\hline 25 & Bulbulcus ibis & 35 & 20 & 30 & 20 & $\mathrm{~W}, \mathrm{M}$ & 105 & LC \\
\hline 26 & Egretta garzetta & 35 & 32 & - & - & $\mathrm{W}, \mathrm{R}$ & 67 & $\mathrm{LC}$ \\
\hline 27 & Ardea bacchus & 15 & - & 29 & - & $\mathrm{W}, \mathrm{M}$ & 44 & $\mathrm{LC}$ \\
\hline 28 & Casmerodius albus & - & - & 30 & - & $\mathrm{W}, \mathrm{R}$ & 30 & LC \\
\hline 29 & Ardea purpurea & - & - & 25 & - & $\mathrm{W}, \mathrm{R}$ & 25 & $\mathrm{LC}$ \\
\hline 30 & Ardeola grayii & - & - & - & 8 & $\mathrm{~W}, \mathrm{M}$ & 8 & $\mathrm{LC}$ \\
\hline
\end{tabular}




\section{Continued}

\begin{tabular}{|c|c|c|c|c|c|c|c|c|}
\hline 31 & Actitis hypoleucos & 25 & - & 57 & - & $\mathrm{W}, \mathrm{M}$ & 82 & LC \\
\hline 32 & Hydrophasianus chirurgus & - & - & 69 & - & $\mathrm{W}, \mathrm{R}$ & 69 & LC \\
\hline 33 & Pluvialis squatarola & - & - & 38 & & $\mathrm{~W}, \mathrm{M}$ & 38 & LC \\
\hline 34 & Rallina fascita & 10 & - & 4 & - & $\mathrm{W}, \mathrm{R}$ & 14 & LC \\
\hline 35 & Porphyrio porphyrio & - & - & 105 & - & $\mathrm{W}, \mathrm{R}$ & 105 & LC \\
\hline 36 & Gallinula choloropus & - & - & 25 & - & $\mathrm{W}, \mathrm{R}$ & 25 & LC \\
\hline 37 & Metopidius indicus & - & - & 17 & - & $\mathrm{W}, \mathrm{R}$ & 17 & LC \\
\hline 38 & Merops orientalis & 15 & - & 23 & 16 & $\mathrm{~T}, \mathrm{R}$ & 54 & LC \\
\hline 39 & Halcyon smyrnensis & 6 & - & 9 & - & $\mathrm{T}, \mathrm{R}$ & 15 & LC \\
\hline 40 & Coracias benghalensis & - & 5 & - & 10 & $\mathrm{~T}, \mathrm{R}$ & 15 & LC \\
\hline 41 & Streptopelia chinensis & 8 & 16 & - & 8 & $\mathrm{~T}, \mathrm{R}$ & 32 & LC \\
\hline 42 & Streptopelitr anquebarica & 20 & 30 & 20 & 22 & $\mathrm{~T}, \mathrm{R}$ & 92 & LC \\
\hline 43 & Chalcophaps indica & - & - & - & 14 & $\mathrm{~T}, \mathrm{R}$ & 14 & LC \\
\hline 44 & Milvus migrans & 26 & - & 10 & - & $\mathrm{T}, \mathrm{R}$ & 36 & LC \\
\hline 45 & Aviceda jerdoni & - & - & - & 5 & $\mathrm{~T}, \mathrm{R}$ & 5 & LC \\
\hline 46 & Pandion haliaetus & 15 & - & - & 12 & $\mathrm{~T}, \mathrm{M}$ & 27 & LC \\
\hline 47 & Dedrocygna javanica & 50 & - & 55 & 1 & $\mathrm{~W}, \mathrm{R}$ & 106 & LC \\
\hline 48 & Nettapus coromandelianus & - & - & 71 & - & $\mathrm{W}, \mathrm{R}$ & 71 & LC \\
\hline 49 & Tachybaptus ruficollis & - & - & 32 & - & $\mathrm{W}, \mathrm{R}$ & 32 & $\mathrm{LC}$ \\
\hline \multirow[t]{3}{*}{50} & Phalacrocorax niger & - & - & 55 & - & $\mathrm{W}, \mathrm{R}$ & 55 & LC \\
\hline & Total numbers & 548 & 440 & 1212 & 467 & & 2667 & \\
\hline & Total species & 24 & 21 & 33 & 25 & & 50 & \\
\hline
\end{tabular}

$\mathrm{T}=$ Terrestrial bird, $\mathrm{W}=$ water bird, $\mathrm{R}=$ restria birds, $\mathrm{M}=$ migratory bird .

the birds as a shelter and also the foods of insects and fruits, and breeding sites as well. Total of 25 species were recorded from it, especially the birds are forest birds (Table 2).

For the seasonal variation of bird species in that area, highest species number was collected during cool season and lowest number was in the wet season (Table 3). It was quite clear that this study area was visited by the migratory bird species during the cool season.

According to abundance category index, two abundance, two common species, three frequent species, seven uncommon species and 36 rare species were observed in this study area (Table 4). Krebs (2001) [10]. Stated that rare species are the most and abundance species are low in number in stable ecosystem. Hence, there could be assumed as stable environment and still be good ecosystem.

According to the diversity index calculated by Shannon Weiner formula, the study area of Taungoo environs could be assessed as diversed area in relation to the bird fauna (Shannan Weiner $H^{\prime}=\Sigma P i \operatorname{Ln} P i=3.02162$ ). Shannon-Weiner in- 
dix value of each bird species were routingly directly related with the observed individual numbers. According to Shannon Evenness value $\left(H^{\prime} / S=-0.00132218\right)$, the data showed that the bird species recorded from the one habitat was not the similar to another) (Table 7 and Table 8).

Table 7. Diversity and seasonal distribution of Recorded birds species on the study areas.

\begin{tabular}{|c|c|c|c|c|c|c|c|c|c|}
\hline No. & Scientific Name & Dry & Wet & Cool & Total & $P i$ & $\operatorname{Ln}$ & $\operatorname{Ln} P i$ & $P i \operatorname{Ln} P i$ \\
\hline 1 & Dicrurus macrocercus & 100 & 120 & 150 & 370 & 0.05435 & -2.91235 & -0.15828 & -0.0086 \\
\hline 2 & Dicrurus leucophaeus & 500 & 350 & 650 & 1500 & 0.22033 & -1.51263 & -0.33328 & -0.0734 \\
\hline 3 & Dicrurus aeneus & - & 8 & 15 & 23 & 0.00338 & -5.69047 & -0.01922 & -0.0001 \\
\hline 4 & Corvus splendens & 50 & 53 & 65 & 168 & 0.02468 & -3.70188 & -0.09135 & -0.0023 \\
\hline 5 & Dendrocitta vagabunda & - & 1 & 3 & 4 & 0.00059 & -7.43878 & -0.00437 & 0.0000 \\
\hline 6 & Motacilla alba & - & - & - & & 0.00000 & 0.00000 & 0.00000 & 0.0000 \\
\hline 7 & Passer domesticus & 250 & 222 & 260 & 732 & 0.10752 & -2.23007 & -0.23978 & -0.0258 \\
\hline 8 & Passer flaveolus & - & - & - & 0 & 0.00000 & 0.00000 & 0.00000 & 0.0000 \\
\hline 9 & Pycnonotus atriceps & 8 & 10 & 16 & 34 & 0.00499 & -5.29918 & -0.02646 & -0.0001 \\
\hline 10 & Pycnonotus blanfordi & 500 & 550 & 600 & 1650 & 0.24236 & -1.41732 & -0.34351 & -0.0833 \\
\hline 11 & Pycnonotus cafer & - & 10 & 16 & 26 & 0.00382 & -5.56777 & -0.02126 & -0.0001 \\
\hline 12 & Sturnus burmannicus & - & 1 & 2 & 3 & 0.00044 & -7.72647 & -0.00340 & 0.0000 \\
\hline 13 & Arcridotheres fuscus & 20 & 21 & 25 & 66 & 0.00969 & -4.63625 & -0.04495 & -0.0004 \\
\hline 14 & Arcridotheres tristis & - & 6 & 4 & 10 & 0.00147 & -6.52317 & -0.00958 & 0.0000 \\
\hline 15 & Lanius cristatus & - & 5 & 5 & 10 & 0.00147 & -6.52317 & -0.00958 & 0.0000 \\
\hline 16 & Lanius schach & - & 2 & 4 & 6 & 0.00088 & -7.03445 & -0.00620 & 0.0000 \\
\hline 17 & Centropus sinensis & - & 6 & 7 & 13 & 0.00191 & -6.26065 & -0.01195 & 0.0000 \\
\hline 18 & Eurystomus orientalis & - & - & - & & 0.00000 & 0.00000 & 0.00000 & 0.0000 \\
\hline 19 & Nectarinia asiatica & 150 & 145 & 180 & 475 & 0.06977 & -2.66254 & -0.18577 & -0.0130 \\
\hline 20 & Muscicapa dauurica & - & 2 & 5 & 7 & 0.00103 & -6.88014 & -0.00707 & 0.0000 \\
\hline 20 & Hirundo rustica & - & 2 & 5 & 7 & 0.00103 & -6.88014 & -0.00707 & 0.0000 \\
\hline 21 & Saxicola caprata & 350 & 400 & 450 & 1200 & 0.17626 & -1.73778 & -0.30631 & -0.0540 \\
\hline 22 & Oriolus tenuirostris & - & 5 & 8 & 13 & 0.00191 & -6.26065 & -0.01195 & 0.0000 \\
\hline 23 & Alauda gulgula & - & - & - & & 0.00000 & 0.00000 & 0.00000 & 0.0000 \\
\hline 24 & Bulbulcus ibis & - & 8 & 10 & 18 & 0.00264 & -5.93546 & -0.01569 & 0.0000 \\
\hline 25 & Egretta garzetta & 200 & 250 & 400 & 850 & 0.12485 & -2.08062 & -0.25977 & -0.0324 \\
\hline 26 & Ardea bacchus & - & 6 & 11 & 17 & 0.00250 & -5.99267 & -0.01496 & 0.0000 \\
\hline 27 & Casmerodius albus & - & 30 & 45 & 75 & 0.01102 & -4.50841 & -0.04967 & -0.0005 \\
\hline 28 & Ardea purpurea & - & 8 & 15 & 23 & 0.00338 & -5.69047 & -0.01922 & -0.0001 \\
\hline 29 & Ardeola grayii & - & 9 & 10 & 19 & 0.00279 & -5.88136 & -0.01641 & 0.0000 \\
\hline 30 & Actitis hypoleucos & - & 5 & 8 & 13 & 0.00191 & -6.26065 & -0.01195 & 0.0000 \\
\hline 31 & Hydrophasianus chirurgus & - & 120 & 175 & 295 & 0.04333 & -3.13889 & -0.13601 & -0.0059 \\
\hline
\end{tabular}




\section{Continued}

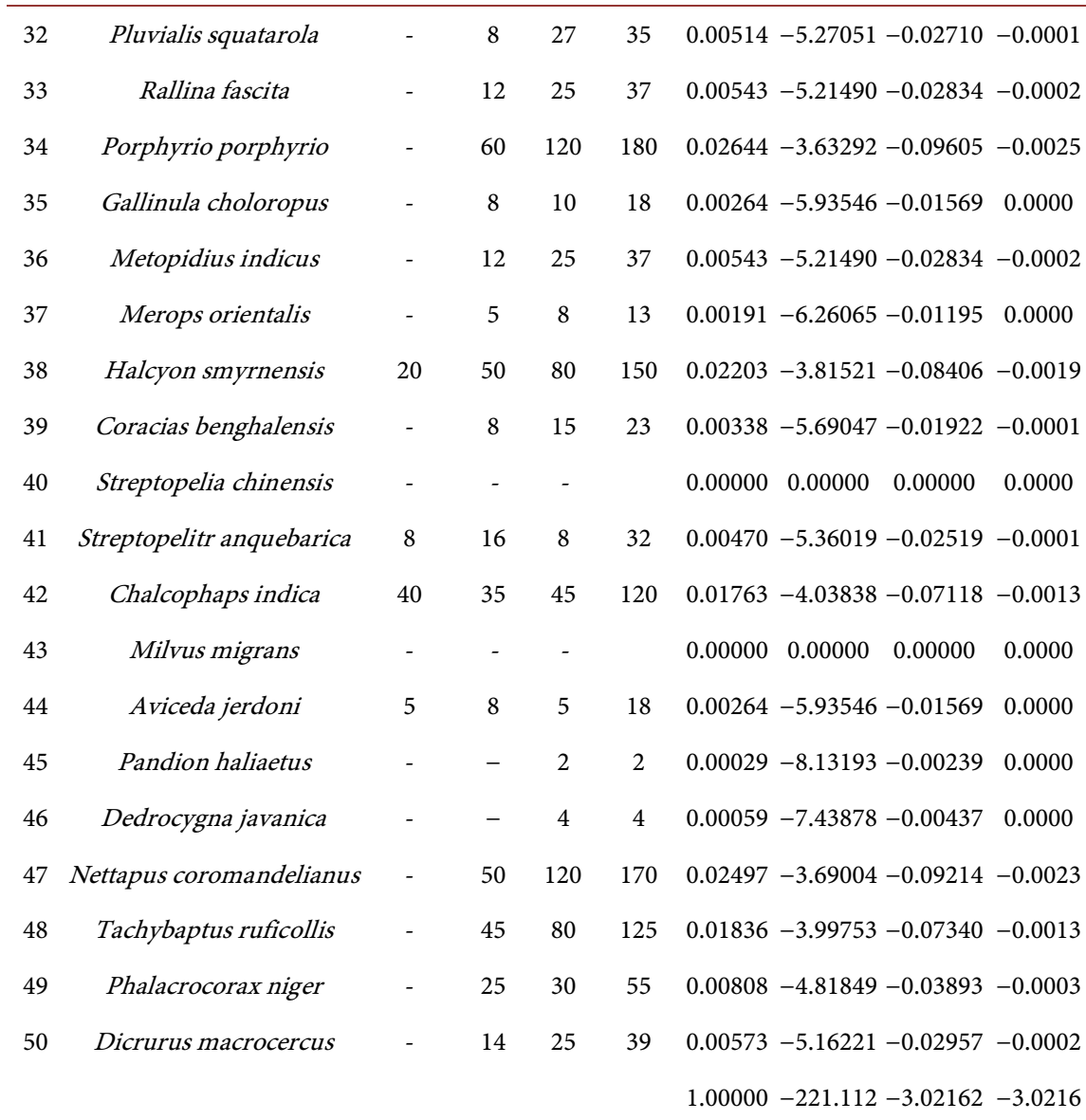

Table 8. Diversity index value of birds of taungoo environs during study period.

\begin{tabular}{cccc}
\hline No. & Diversity index & Formula & Index value \\
\hline 1. & Shannan Weiner & $H^{\prime}=\Sigma P I \operatorname{Ln} P i$ & -3.02162 \\
2. & Eveness & $E=H^{\prime} / S$ & -0.00132218 \\
\hline
\end{tabular}

Similarly, the species, Arcridotherestristics was recorded as the largest numbers (217 birds and $P i \operatorname{Ln} P i=0.016658909)$ and the second highest numbers was from the species Hirundorustica (203 birds and $P i \operatorname{Ln} P i=0.014966546)$ and third one was Passer domesticus (175 birds and PiLnPi $=0.010684033$ ) (Table 8). These species could be concluded as the most common bird species. The species Aricedajerdoni was recorded as the least numbers (5 birds) and two species $\mathrm{Mus}^{-}$ cicappadatuurica and Ardeolagrayii were observed as the second least numbers ( 8 birds in each species). Another eight more species were recorded under observed numbers of 20 individuals. Those ten species were concluded as the rare species. These species urgently need to be investigated what kinds of impacts and how to conserve those species (Table 4 and Table 7). Haslem and Bennet (2008) [11] stated that high diversity of bird fauna in the agricultural land can have the beneficial aspect by the increase of crop yields by controlling the pest species bi- 
ologically. Conclusively, the present study area is rich in bird species indicating that this area was healthy and still stable environment.

\section{Conclusion}

Species composition of bird fauna from Taungoo Environs was similar to that of other areas in the research. All bird species were found to equal distribution in all habitat types of the present study area. The rare species was highest and abundance and common species were few that means this study was balance ecosystem. According to index value of Shannon diversity assessment, this area was indicated as one of the highest bird diversity. According to above mentioned facts, it can be concluded that Taungoo environs was still in healthy ecosystem.

\section{Conflicts of Interest}

The authors declare no conflicts of interest regarding the publication of this paper.

\section{References}

[1] Gill, F.B. (2001) Ornithology. 2nd Edition, Wtt. Freeman and Company, New York.

[2] Phaw, N.L.L. (2016) Habitat Utilization of Bird Species Recorded from Some Areas of Taungoo Environs. M.Sc. Thesis, Taungoo University, Taungoo.

[3] Dwe, M.M. (2014) Survey of the Bird Fauna of Taungoo Environs. Report, Unpublished, Taungoo University, Taungoo.

[4] Bibby, C., Jones, M. and Marsden, S. (1998) Expedition Field Techniques, Bird Surveys. Royal Geographical Society (with Institution of British Geographers) I Kenington Gore London. www.rgs.org

[5] Robson, C. (2008) A Field Guide to the Birds of Thailand and South-East Asia. New Holland Publishers (UK) Ltd.

[6] Thwin, K.N.L.K.M.M. (2003) The Birds of Myanmar. Wildlife Conservation Society (Myanmar Program).

[7] Smythies, B.E. (1986) The Birds of Burma. 3rd Edition, Nimrod Press Ltd. and Silvio Mattacehione Co.

[8] Kumar, S. and Sivaperuman, C. (2005) Bird Community Structure In: Robson, C., $A$ Field Guide to the Birds of Thailand and South-East Asia, New Holland Publishers (UK) Ltd.

[9] Stilling, P. (1999) Ecology Theolories and Application. 3rd Edition, Upper Saddle river, Prentice-Hall, Inc.

[10] Krebs, C.J. (2001) Ecology: The Experimental Analysis of Distribution and Abundance. Benjmin Cumming. An Imprint of Addison Wesley Longman, Inc., New York.

[11] Haslem, A. and Bennett, A.F. (2008) Birds in Agricultural Mosaics: The Influence of Landscape Patterns Countryside Heterogeneity. Ecological Applications, Wiley Only Library. https://doi.org/10.1890/07-0692.1 